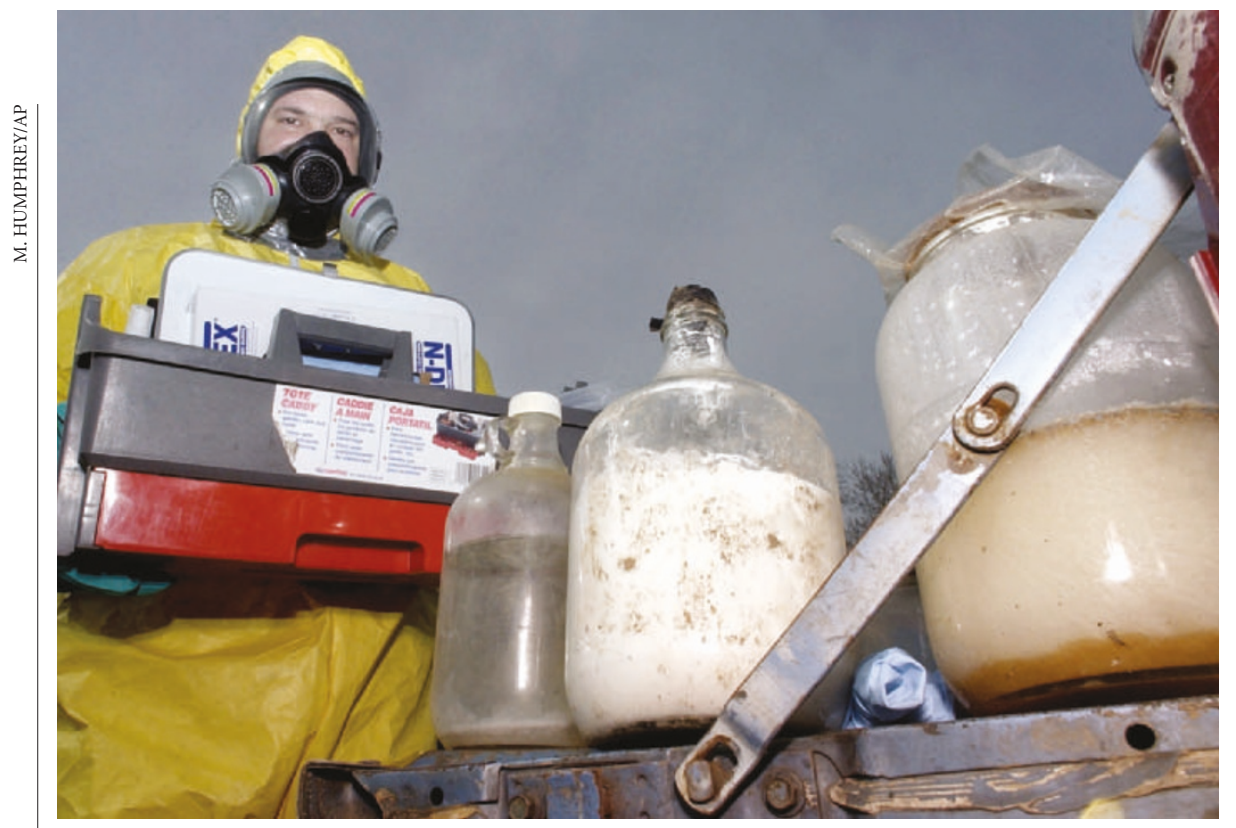

It's a wrap: a Tennessee cop wrestles with the remains of a home lab for making methamphetamine.

\section{Police urge speedy action to clean up home drug factories}

Emma Marris, Washington

Abuse of methamphetamine is creeping across the United States from the west coast, producing a welter of toxic home labs, a congressional committee heard last week.

The drug, a cheap, potent and highly addictive stimulant, can be 'cooked' on a hotplate from easily acquired ingredients such as cold remedies and fertilizers. And the mess left behind can affect the health of police who raid the premises, children who live there, and even subsequent tenants.

"During the cook, it reaches levels that can be extremely toxic," says John Martyny, a toxicologist at the National Jewish Medical and Research Center in Denver, Colorado, who testified at the hearing.

After complaints from police in his district east of Nashville, where 'meth' use has boomed in a big way, congressman Bart Gordon (Democrat, Tennessee) put together a bill to fund research into the drug's health risks and to devise standards for decontamination. The bill's bipartisan supporters expect it to move speedily into law.

If enacted, the bill will charge the Environmental Protection Agency (EPA) and the National Institute of Standards and Technology with researching the health risks of meth labs and setting standards for decontamination, as well as funding the development of better field-test kits.

Meth users who make their own drug do so wherever they can: at home, in motels, even in cars. Various recipes exist — most are available on the Internet — but even the simplest are dangerous and toxic. Typically, ephedrine is separated from a decongestant using solvents, then added to chemicals such as ammonia, hydrochloric acid, phosphorus or iodine. The resulting methamphetamine is a fine particulate that gets everywhere. And many of the chemicals involved are absorbed by porous surfaces such as carpets, curtains, wallpaper and clothes.

SheriffDavid Andrews of Putnam County, Tennessee, says he hates entering meth labs. "Every time I go around one, I get a headache, and I have a detective who breaks out in red blotches," he says. Setting standards would not only help law enforcement, Andrews points out, but also mortgage lenders who, without a decontamination standard, must take a financial loss when they repossess a house that has been used as a meth lab.

Julie Mazzuca is president of the Meth Lab Cleanup Company based in Post Falls, Idaho, where business is booming. She and her crew charge a few thousand dollars to don respirators and scrub away traces of methamphetamine from meth labs. She has seen the health effects at first hand. "You see respiratory problems, throat irritation, skin irritation and nausea," she says.

Meth sites, Mazzuca says, are unbelievably filthy. "On one of my first clean-ups I removed seven tonnes of residue from a mobile home," she says.

Although anecdotal evidence shows that meth labs are unhealthy, there is little research on the subject. Some US states have standards for detectable levels of methamphetamine, but they are based on the detection technology rather than knowledge of the health risks. "There's a lot of seat-of-thepants stuff going on with these clean-ups," says Charles Salocks, a toxicologist with the California EPA.
Science agencies get fresh paymasters in Republican revamp

Geoff Brumfiel, Washington

NASA and the National Science

Foundation (NSF) will answer to a new set of masters in Congress, following a wide-ranging shake-up of the committees that set their budgets.

In changes pushed through by the Republican leadership in both the Senate and the House of Representatives, the appropriations subcommittees that dealt with the two science agencies as well as a range of other programmes, from housing to veterans' affairs have been abolished.

NASA and the NSF will now be overseen by new subcommittees, where they will compete for funds with the Department of Commerce, the criminaljustice system and the state department.

It isn't yet clear what the change will mean for the agencies' budgets. But it poses a challenge to agency chiefs, who now have to explain what they do to a new set of people in Congress, beginning at hearings this week. "Change is good," says Arden Bement, director of the NSF, adding caustically that "sometimes, no change would be even better".

The House and Senate subcommittees are now chaired by, respectively, Frank Wolf (Republican, Virginia) and Richard Shelby (Republican, Alabama). Shelby crossed swords with scientific leaders in 1999 when he championed a bill to open up scientists' data for scrutiny by industry groups (see Nature 397, 459; 1999).

But many of the new committees' members have had scant dealings with science agencies in the past. "We have a whole new group of people who need to be educated about the importance of the NSF and NASA," says Tobin Smith of the congressional affairs office at the Washington-based Association of American Universities.

Each year, the subcommittees take the president's budget request and convert it into the final budgets received by agencies and government departments. The process is heavily dependent on the personalities involved, and the NSF, in particular, has benefited in recent years from allies on the old subcommittees who sometimes gave it more money than the White House requested.

Both Shelby and Barbara Mikulski (Democrat, Maryland), the top Democrat on the Senate committee, have major NASA facilities in their states, which should ensure strong support for the space agency, some lobbyists note. 